J Res Dentomaxillofac Sci

JRDMS Journal of Research in Dental and Maxillofacial Sciences

\title{
Clinical Significance of Salivary Biomarkers in Oral Squamous Cell Carcinoma: A Review
}

\author{
Manzarpour M1ㅗㅇ Homaie $\mathbf{M}^{1}$,Farhadi $\mathrm{S}^{\mathbf{2}}$ \\ ${ }^{l}$ Student of Dentistry, Dental Branch of Tehran, Islamic Azad University, Tehran, Iran \\ ${ }^{2}$ Assistant Professor, Oral \& Maxillofacial Pathology Dept, Dental Branch of Tehran, Islamic Azad University, Tehran, Iran
}

\begin{tabular}{l}
\hline ARTICLE INFO \\
\hline Article Type \\
Review Article \\
\hline Article History \\
Received: Apr 2017 \\
Accepted: May 2017 \\
ePublished: June 2017 \\
Keywords: \\
Oral Squamous Cell \\
Carcinoma, \\
Biomarkers, Diagnosis, \\
Prognosis, Treatment \\
Outcome
\end{tabular}

\begin{abstract}
Background and Aim:Oral squamous cell carcinoma (OSCC) accounts for approximately $3 \%$ of all cancers worldwide, and if diagnosed early, it has a five-year survival rate of around $85 \%$; however, a late diagnosis may decrease the survival rate to $50 \%$. Aberrant expression of several genes is associated with the hallmarks of OSCC including uncontrolled cell proliferation, poor differentiation, invasion, metastasis, and angiogenesis. The potential of molecular biomarkers for the diagnosis, prognosis, or monitoring of the treatment efficacy in OSCC has been extensively explored during the last decades. This study aimed to review the significance of salivary biomarkers in the treatment outcome of OSCC.

Materials and Methods: The articles in scientific databases including Google Scholar, ScienceDirect, Medline, and PubMed, published between 2004 and 2017, were searched by using relevant keywords including OSCC, biomarkers, diagnosis, prognosis and treatment outcome. Thirty-four articles were reviewed in this study.

Results: According to the findings of the reviewed studies, several salivary biomarkers including subcutaneous adipose tissue (SAT), interleukin-8 (IL-8), Cyfra 21-1, 8-hydroxy-2-deoxyguanosine, malondialdehyde, lactate dehydrogenase (LDH), Annexin A8, ErbB2, carcinoembryonic antigen (CEA), C-reactive protein (CRP), and salivary proteomic biomarkers might be used as indicators for the detection of oral cancer and premalignant oral disease (PMOD) and as a potential marker in the prognosis of OSCC.

Conclusion: Salivary biomarker analysis seems to be a major advancement in the diagnosis of OSCC, and it is a fast-developing field in scientific research. The results indicate that salivary biomarkers can be useful diagnostic and prognostic tools in OSCC.
\end{abstract}

Please cite this paper as: Manzarpour M, Homaie M, Farhadi S. Clinical Significance of Salivary Biomarkers in Oral Squamous Cell Carcinoma: A Review. J Res Dent maxillofac Sci.2017;2(3):22-30. 


\section{Introduction:}

Oral squamous cell carcinoma (OSCC) accounts for approximately $3 \%$ of all cancers worldwide. (1) $^{(1)}$ OSCC comprises more than $90 \%$ of all oral cancers, ${ }^{(2,3)}$ and if diagnosed early, it has a five-year survival rate of about $85 \% .{ }^{(4)}$ Nowadays, even with various scientific advancements being explored and discovered every day, the worldwide prognosis of oral cancer has diminished rather than improved. This is a recognized public health care problem with a high mortality and morbidity rate. ${ }^{(5)}$

A wide range of molecules is involved in oral carcinogenesis. Aberrant expression of several genes is linked with the hallmarks of OSCC including uncontrolled cell proliferation, defective apoptosis, poor differentiation, epithelial/mesenchymal transition, metastasis, and angiogenesis. ${ }^{(6)}$ The potential of molecular biomarkers for the diagnosis, prognosis, or monitoring of the treatment outcome in OSCC has been vastly explored during the last decades. In the era of personalized medicine, immunohistochemical detection and/or mRNA expression profiling of molecular biomarkers are expected to significantly contribute to the development of new screening tests with a high sensitivity and specificity and tailor-made therapies for OSCC.(7)

Saliva contains a large number of proteins and peptides, which are used as biomarkers for the detection of different oral and systemic diseases. Saliva is one of the most candid tools for the diagnosis of OSCC because of its direct contact with oral cancerous lesions. ${ }^{(8)}$ Salivary biomarkers have been proven as cost-effective adjuncts in the diagnosis of oral and oropharyngeal carcinoma. ${ }^{(8)}$ In their review on salivary genomics in oral cancer, Shah et al have insisted that saliva is a potential biomarker for OSCC as it contains locally expressed proteins including alpha-amylase, lactoferrins, lysozymes, proline-rich proteins, mucins, histatins, cystatins, and transferrin. ${ }^{(8)}$ Markopoulos et al stated that the molecular diagnosis of OSCC can be done at three levels. ${ }^{(9)}$ Alterations in the cellular DNA causes variations in mRNA transcripts and intra-cellular or extracellular protein levels. Salivary biomarkers can be genetic, protein, or metabolomic markers. ${ }^{(10)}$

Considering the wide range of salivary biomarkers, this study aimed to review the related recent studies in this field to summarize and help significance s of OSCC.

\section{Methods and Materials:}

The literature over the past 13 years (20042017) were searched through Google Scholar, ScienceDirect, Medline and PubMed databases by using relevant keywords including OSCC, biomarkers, diagnosis, prognosis, and treatment outcome. Finally, 34 articles were reviewed in this study.

\section{Results:}

The findings of the reviewed studies indicated that the majority of salivary biomarkers including subcutaneous adipose tissue (SAT), interleukin-8 (IL-8), Cyfra 21-1, 8-hydroxy2-deoxyguanosine, malondialdehyde, lactate dehydrogenase (LDH), Annexin A8, ErbB2, carcinoembryonic antigen (CEA), C-reactive protein (CRP), and salivary proteomic biomarkers might be used as indicators for the detection of oral cancer and premalignant oral disease (PMOD) and as a potential marker in the prognosis of OSCC. Table 1 demonstrates the summary of the reviewed studies. 
Table 1- Summary of the reviewed studies

\begin{tabular}{|c|c|c|c|c|c|}
\hline No & Title & $\begin{array}{l}\text { Authors/Date } \\
\text { of publication }\end{array}$ & Sample volume & Biomarkers/methods & Conclusions \\
\hline 1 & $\begin{array}{l}\text { Chronic periodontitis can } \\
\text { affect the levels of potential } \\
\text { oral cancer salivary mRNA } \\
\text { biomarkers }^{(11)}\end{array}$ & $\begin{array}{l}2017 \\
\text { Cheng et al }\end{array}$ & $\begin{array}{l}105 \text { human subjects: OSCC, } \\
\text { periodontitis, and healthy } \\
\text { controls }\end{array}$ & $\begin{array}{l}\text { S100P mRNA/pre-amplification } \\
\text { reverse transcription-quantitative } \\
\text { PCR }\end{array}$ & $\begin{array}{l}\text { Salivary S100P mRNA could } \\
\text { be a reliable biomarker for } \\
\text { OSCC detection, regardless of } \\
\text { the presence of chronic } \\
\text { periodontitis. }\end{array}$ \\
\hline 2 & $\begin{array}{l}\text { Development of a } \\
\text { Multiplexed Liquid } \\
\text { Chromatography Multiple- } \\
\text { Reaction-Monitoring Mass } \\
\text { Spectrometry (LC-MRM/MS) } \\
\text { Method for Evaluation of } \\
\text { Salivary Proteins as Oral } \\
\text { Cancer Biomarkers. }{ }^{(12)}\end{array}$ & $\begin{array}{l}2017 \\
\text { Chen et al }\end{array}$ & 109 & $\begin{array}{l}56 \text { salivary proteins/simple and } \\
\text { robust multiple reaction } \\
\text { monitoring (MRM)-based targeted } \\
\text { proteomics approach incorporating } \\
\text { liquid chromatography with mass } \\
\text { spectrometry detection (LC- } \\
\text { MRM/MS) }\end{array}$ & $\begin{array}{l}\text { The results clearly showed a } \\
\text { significant elevation of most } \\
\text { targeted proteins in the } \\
\text { salivary samples obtained } \\
\text { from OSCC patients } \\
\text { compared to the controls. }\end{array}$ \\
\hline 3 & $\begin{array}{l}\text { Metabolomic analysis of the } \\
\text { saliva of Japanese patients } \\
\text { with oral squamous cell } \\
\text { carcinoma. }\end{array}$ & $\begin{array}{l}2017 \\
\text { Ohshima et al }\end{array}$ & $\begin{array}{l}43 \text { (22 Japanese patients } \\
\text { with OSCC and } 21 \text { healthy } \\
\text { controls) }\end{array}$ & $\begin{array}{l}25 \text { metabolites/comprehensive } \\
\text { quantitative metabolomic analysis } \\
\text { using CE-MS. }\end{array}$ & $\begin{array}{l}\text { The findings suggest the } \\
\text { usefulness of metabolites as } \\
\text { salivary biomarkers in } \\
\text { Japanese patients with OSCC. }\end{array}$ \\
\hline 4 & $\begin{array}{l}\text { Salivary IL-8, IL-6 and TNF- } \\
\alpha \text { as Potential Diagnostic } \\
\text { Biomarkers for Oral Cancer. } \\
\text { (14) }\end{array}$ & $\begin{array}{l}2017 \\
\text { Sahibzada et al }\end{array}$ & & Review article & $\begin{array}{l}\text { Chemokines are held } \\
\text { responsible, amongst many } \\
\text { other proinflammatory } \\
\text { cytokines, for inducing oral } \\
\text { cancer. }\end{array}$ \\
\hline 5 & $\begin{array}{l}\text { Serum and salivary levels of } \\
\text { chemerin and MMP-9 in oral } \\
\text { squamous cell carcinoma and } \\
\text { oral premalignant lesions. }{ }^{(15)}\end{array}$ & $\begin{array}{l}2017 \\
\text { Ghallab and } \\
\text { Shaker }\end{array}$ & $\begin{array}{l}45 \text { (15 healthy controls, } 15 \\
\text { patients with oral } \\
\text { premalignant lesions } \\
\text { (OPMLs), and } 15 \text { patients } \\
\text { with early-stage OSCC) }\end{array}$ & $\begin{array}{l}\text { Chemerin and Matrix } \\
\text { metallopeptidase-9 (MMP-9) in } \\
\text { serum and saliva samples/ELISA. }\end{array}$ & $\begin{array}{l}\text { Chemerin and MMP-9 might } \\
\text { be considered as salivary } \\
\text { diagnostic biomarkers for } \\
\text { OPMLs, for early detection of } \\
\text { OSCC, and for detecting early } \\
\text { cancerization of OPMLs. }\end{array}$ \\
\hline 6 & $\begin{array}{l}\text { Salivary biomarkers as tools } \\
\text { for oral squamous cell } \\
\text { carcinoma diagnosis: A } \\
\text { systematic review. }\end{array}$ & $\begin{array}{l}2017 \\
\text { Stuani et al }\end{array}$ & & Review article & $\begin{array}{l}\text { The lack of methodological } \\
\text { criteria within studies and the } \\
\text { absence of a consensus on } \\
\text { marker choice are obstacles } \\
\text { for future studies. }\end{array}$ \\
\hline 7 & $\begin{array}{l}\text { Advances of Salivary } \\
\text { Proteomics in Oral Squamous } \\
\text { Cell Carcinoma (OSCC) } \\
\text { Detection: An Update. }^{(17)}\end{array}$ & $\begin{array}{l}2016 \\
\text { Sannam Khan } \\
\text { et al }\end{array}$ & & Review article & $\begin{array}{l}\text { Due to the easily obtained } \\
\text { characteristics of saliva, the } \\
\text { focus on OSCC has and will } \\
\text { be more shifted to serum and } \\
\text { saliva analysis instead of } \\
\text { tissue analysis. }\end{array}$ \\
\hline 8 & $\begin{array}{l}\text { Salivary biomarkers in oral } \\
\text { squamous cell carcinoma - An } \\
\text { insight }^{(18)}\end{array}$ & $\begin{array}{l}2016 \\
\text { Radhika et al }\end{array}$ & & Review article & $\begin{array}{l}\text { Salivary biomarker analysis } \\
\text { for OSCC is a major } \\
\text { advancement in diagnosis. }\end{array}$ \\
\hline 9 & $\begin{array}{l}\text { Salivary mRNA markers } \\
\text { having the potential to detect } \\
\text { oral squamous cell carcinoma } \\
\text { segregated from oral } \\
\text { leukoplakia with dysplasia. } \\
\text { (19) }\end{array}$ & $\begin{array}{l}2016 \\
\text { Michailidou et } \\
\text { al }\end{array}$ & $\begin{array}{l}85 \text { (34 patients with primary } \\
\text { OSCC, } 20 \text { patients with oral } \\
\text { leukoplakia and dysplasia, } \\
15 \text { patients with mild } \\
\text { dysplasia, } 5 \text { patients with } \\
\text { severe dysplasia/in situ } \\
\text { carcinoma, and } 31 \text { matched } \\
\text { healthy controls })\end{array}$ & $\begin{array}{l}\text { IL-1B, IL-8, OAZ and SAT } \\
\text { mRNA/sequence-specific primers } \\
\text { and real-time RT-PCR }\end{array}$ & $\begin{array}{l}\text { SAT and IL- } 8 \text { mRNAs have a } \\
\text { good discriminatory ability } \\
\text { for OSCC patients only, but } \\
\text { not for patients with oral } \\
\text { leukoplakia, dysplasia or } \\
\text { PMOD. }\end{array}$ \\
\hline
\end{tabular}




\begin{tabular}{|c|c|c|c|c|c|}
\hline No & Title & $\begin{array}{l}\text { Authors/Dat } \\
\text { e of } \\
\text { publication }\end{array}$ & Sample volume & Biomarkers/methods & Conclusions \\
\hline 10 & $\begin{array}{l}\text { Salivary Biomarkers for } \\
\text { Detection of Oral Squamous } \\
\text { Cell Carcinoma in a } \\
\text { Taiwanese Population. }{ }^{(20)}\end{array}$ & $\begin{array}{l}2016 \\
\text { Gleber-Netto } \\
\text { et al }\end{array}$ & $\begin{array}{l}180 \text { (60 OSCC patients, } 60 \\
\text { controls, and } 60 \text { PMOD } \\
\text { patients) }\end{array}$ & $\begin{array}{l}\text { Seven transcriptomic markers } \\
\text { (IL8, IL1 } \beta, \text { SAT1, OAZ1, } \\
\text { DUSP1, S100P, and } \\
\text { H3F3A)/qPCR, and two } \\
\text { proteomic markers (IL8 and } \\
\text { IL1 } \beta \text { ) were evaluated by ELISA. }\end{array}$ & $\begin{array}{l}\text { The combination of } \\
\text { transcriptomic and proteomic } \\
\text { salivary markers is of great } \\
\text { value for oral cancer detection } \\
\text { and differentiation from PMOD } \\
\text { patients and controls. }\end{array}$ \\
\hline 11 & $\begin{array}{l}\text { Correlation of Cyfra } 21-1 \\
\text { levels in saliva and serum } \\
\text { with CK19 mRNA expression } \\
\text { in oral squamous cell } \\
\text { carcinoma. }\end{array}$ & $\begin{array}{l}2016 \\
\text { Malhotra et } \\
\text { al }\end{array}$ & 50 & $\begin{array}{l}\text { Cyfra 21-1 in serum and } \\
\text { salivary ECLIA and CK19 } \\
\text { messenger RNA (mRNA) } \\
\text { expression in tissue by } \\
\text { fluorescent quantitative RT- } \\
\text { PCR. }\end{array}$ & $\begin{array}{l}\text { We advocate salivary Cyfra } 21-1 \\
\text { as a better diagnostic marker } \\
\text { over serum Cyfra } 21-1 \text { as well as } \\
\text { a potential marker in the } \\
\text { prognosis of OSCC. }\end{array}$ \\
\hline 12 & $\begin{array}{l}\text { A non-invasive study to } \\
\text { estimate and compare salivary } \\
\text { sialic acid level as tumor } \\
\text { marker in patients with pre- } \\
\text { cancer and oral cancer. }{ }^{(22)}\end{array}$ & $\begin{array}{l}2016 \\
\text { Jacob et al }\end{array}$ & $\begin{array}{l}60 \text { ( } 20 \text { healthy patients, } 20 \\
\text { cases of oral pre-cancer } \\
\text { patients, and } 20 \text { cases of } \\
\text { OSCC) }\end{array}$ & $\begin{array}{l}\text { Salivary TSA } \\
\text { levels/unstimulated whole } \\
\text { salivary samples were collected } \\
\text { from patients and were } \\
\text { evaluated. }\end{array}$ & $\begin{array}{l}\text { The glycoprotein metabolism is } \\
\text { significantly altered in the saliva } \\
\text { of patients with oral pre-cancer } \\
\text { lesions and OSCC. }\end{array}$ \\
\hline 13 & $\begin{array}{l}\text { A review on oral cancer } \\
\text { biomarkers: Understanding } \\
\text { the past and learning from the } \\
\text { present. }{ }^{(23)}\end{array}$ & $\begin{array}{l}2016 \\
\text { Santosh et al }\end{array}$ & & Review article & $\begin{array}{l}\text { Development of clinically valid } \\
\text { candidate biomarkers with } \\
\text { greater clinical utility values for } \\
\text { oral cancer screening is highly } \\
\text { recommended. }\end{array}$ \\
\hline 14 & $\begin{array}{l}\text { Salivary 8-hydroxy-2- } \\
\text { deoxyguanosine, } \\
\text { malondialdehyde, vitamin C, } \\
\text { and vitamin E in oral pre- } \\
\text { cancer and cancer: diagnostic } \\
\text { value and free radical } \\
\text { mechanism of action. }\end{array}$ & $\begin{array}{l}2016 \\
\text { Kaur et al }\end{array}$ & $\begin{array}{l}160 \text { (40 OSCC, } 40 \text { oral lichen } \\
\text { planus lesions, } 40 \text { oral } \\
\text { leukoplakia, } 40 \text { oral } \\
\text { submucous fibrosis, and a } \\
\text { control group) }\end{array}$ & $\begin{array}{l}\text { Salivary } 8-\mathrm{OHdG}, \mathrm{MDA} \text {, and } \\
\text { vitamins } \mathrm{C} \text { and } \mathrm{E} \text { were } \\
\text { measured in unstimulated saliva. }\end{array}$ & $\begin{array}{l}\text { Presence of oxidative DNA and } \\
\text { lipid damage in pre-cancerous } \\
\text { and OSCC patients. Detection of } \\
\text { salivary } 8 \text {-OHdG, MDA, } \\
\text { vitamin C, and vitamin E can act } \\
\text { as suitable diagnostic } \\
\text { biomarkers of oral pre-cancer } \\
\text { and cancerous lesions. }\end{array}$ \\
\hline 15 & $\begin{array}{l}\text { Salivary Lactate } \\
\text { Dehydrogenase (LDH)- A } \\
\text { Novel Technique in Oral } \\
\text { Cancer Detection and } \\
\text { Diagnosis. }\end{array}$ & $\begin{array}{l}2016 \\
\text { Lokesh et al }\end{array}$ & $\begin{array}{l}50 \text { (30 OSCC patients and } 20 \\
\text { healthy controls) }\end{array}$ & $\begin{array}{l}\text { LDH values/unstimulated } \\
\text { salivary samples collected from } \\
\text { the selected patients were } \\
\text { centrifuged and processed. }\end{array}$ & $\begin{array}{l}\text { LDH values were significantly } \\
\text { higher in patients with OSCC. } \\
\text { Furthermore, the levels } \\
\text { significantly correlated with the } \\
\text { histopathological grade of the } \\
\text { tumor. }\end{array}$ \\
\hline 16 & $\begin{array}{l}\text { Annexin A8 is a novel } \\
\text { molecular marker for } \\
\text { detecting lymph node } \\
\text { metastasis in oral squamous } \\
\text { cell carcinoma. }(26)\end{array}$ & $\begin{array}{l}2016 \\
\text { Oka et al }\end{array}$ & 13 & $\begin{array}{l}\text { KRT19 and ANXA8 } \\
\text { mRNA/microarray analysis }\end{array}$ & $\begin{array}{l}\text { Both KRT19 and ANXA8 } \\
\text { mRNA may be useful markers } \\
\text { for detecting lymph node } \\
\text { metastases in OSCC patients. }\end{array}$ \\
\hline 17 & $\begin{array}{l}\text { Salivary Levels of ErbB2 and } \\
\text { CEA in Oral Squamous Cell } \\
\text { Carcinoma Patients. }{ }^{(27)}\end{array}$ & $\begin{array}{l}2016 \\
\text { Honarmand } \\
\text { et al }\end{array}$ & 53 & ErbB2, CEA/ELISA & $\begin{array}{l}\text { The role of ErbB2 as a tumor } \\
\text { marker in patients with OSCC } \\
\text { must still be regarded as } \\
\text { controversial. In contrast, the } \\
\text { salivary level of CEA may find } \\
\text { application for early detection of } \\
\text { patients. }\end{array}$ \\
\hline 18 & $\begin{array}{l}\text { Altered serum and salivary C- } \\
\text { reactive protein levels in } \\
\text { patients with oral } \\
\text { premalignant lesions and oral } \\
\text { squamous cell carcinoma. }\end{array}$ & $\begin{array}{l}2016 \\
\text { Metgud and } \\
\text { Bajaj }\end{array}$ & $\begin{array}{l}60 \text { (20 healthy individuals, } 20 \\
\text { patients with OPMLs, and } 20 \\
\text { OSCC patients) }\end{array}$ & $\begin{array}{l}\text { Serum and salivary CRP levels } \\
\text { were evaluated in salivary and } \\
\text { blood samples. }\end{array}$ & $\begin{array}{l}\text { Mean CRP levels were higher in } \\
\text { patients with oral premalignant } \\
\text { lesions compared to the controls. } \\
\text { CRP levels in OSCC patients } \\
\text { were elevated and were } \\
\text { associated with advanced tumor } \\
\text { stages. }\end{array}$ \\
\hline
\end{tabular}




\begin{tabular}{|c|c|c|c|c|c|}
\hline No & Title & $\begin{array}{l}\text { Authors/Dat } \\
\text { e of } \\
\text { publication }\end{array}$ & Sample volume & Biomarkers/methods & Conclusions \\
\hline 19 & $\begin{array}{l}\text { Potential Salivary Proteomic } \\
\text { Markers of Oral Squamous } \\
\text { Cell Carcinoma. }\end{array}$ & $\begin{array}{l}2016 \\
\text { Gallo et al }\end{array}$ & $\begin{array}{l}75 \text { (45 OSCC patients and } 30 \\
\text { healthy controls) }\end{array}$ & $\begin{array}{l}\text { Saliva proteome/SELDI-TOF } \\
\text { mass spectrometry of saliva }\end{array}$ & $\begin{array}{l}\text { The saliva proteome presents } \\
\text { significant modifications in } \\
\text { OSCC patients and may be } \\
\text { useful for knowledge } \\
\text { advancement regarding oral } \\
\text { carcinogenesis and definition of } \\
\text { diagnostic and prognostic } \\
\text { biomarkers. }\end{array}$ \\
\hline 20 & $\begin{array}{l}\text { Insights into immune } \\
\text { responses in oral cancer } \\
\text { through proteomic analysis of } \\
\text { saliva and salivary } \\
\text { extracellular vesicles. }\end{array}$ & $\begin{array}{l}2015 \\
\text { Winck et al }\end{array}$ & 58 & $\begin{array}{l}\text { The proteome of whole saliva } \\
\text { and salivary extracellular } \\
\text { vehicles (EVs) from patients } \\
\text { with OSCC and healthy } \\
\text { individuals were analyzed by } \\
\text { LC-MS/MS and label-free } \\
\text { protein quantification. }\end{array}$ & $\begin{array}{l}\text { The saliva proteome analysis } \\
\text { revealed that immune processes } \\
\text { are related to the presence of } \\
\text { OSCC and indicated that } \\
\text { proteomics data can contribute } \\
\text { to determining OSCC prognosis. }\end{array}$ \\
\hline 21 & $\begin{array}{l}\text { Salivary microRNAs in oral } \\
\text { cancer. }{ }^{(31)}\end{array}$ & $\begin{array}{l}2015 \\
\text { Zahran et al }\end{array}$ & $\begin{array}{l}100 \text { (20 healthy controls, } 40 \\
\text { PMDs, } 20 \text { biopsy-confirmed } \\
\text { OSCC, and } 20 \text { recurrent } \\
\text { aphthous stomatitis (RAS) as } \\
\text { controls) }\end{array}$ & $\begin{array}{l}\text { MicroRNA Isolation Kit } \\
\text { (Qiagen, UL)/miRNA } \\
\text { expression analysis was } \\
\text { performed using qRT-PCR } \\
\text { (Applied Biosystems). }\end{array}$ & $\begin{array}{l}\text { Salivary determination of the } \\
\text { miRNAs (miRNA-21, miRNA- } \\
\text { 184, and miRNA-145) might } \\
\text { furnish a noninvasive and rapid } \\
\text { adjunctive aid for revealing } \\
\text { malignant transformations in } \\
\text { oral mucosal lesions, particularly } \\
\text { miRNA-184. }\end{array}$ \\
\hline 22 & $\begin{array}{l}\text { Salivary and serum level of } \\
\text { CYFRA } 21-1 \text { in oral } \\
\text { precancer and oral squamous } \\
\text { cell carcinoma. }{ }^{(32)}\end{array}$ & $\begin{array}{l}2015 \\
\text { Rajkumar et } \\
\text { al }\end{array}$ & $\begin{array}{l}100 \text { (premalignant subjects } \\
\text { and normal healthy subjects) }\end{array}$ & $\begin{array}{l}\text { Serum and salivary CYFRA 21- } \\
1 \text { levels/ELISA. Appropriate } \\
\text { statistical tests. }\end{array}$ & $\begin{array}{l}\text { The outcome of this study } \\
\text { suggests that salivary CYFRA } \\
21-1 \text { can be utilized as a } \\
\text { biomarker for early detection of } \\
\text { oral cancer. }\end{array}$ \\
\hline 23 & $\begin{array}{l}\text { Salivary Immunosuppressive } \\
\text { Cytokines IL-10 and IL-13 } \\
\text { are Significantly Elevated in } \\
\text { Oral Squamous Cell } \\
\text { Carcinoma Patients. }\end{array}$ & $\begin{array}{l}2015 \\
\text { Aziz et al }\end{array}$ & $\begin{array}{l}63 \text { (30 OSCC patients and } 33 \\
\text { age- and gender-matched } \\
\text { healthy controls) }\end{array}$ & $\begin{array}{l}\text { Immunosuppressive cytokines } \\
\text { including IL-4, IL-10, IL-13, } \\
\text { and IL-1RA were evaluated in } \\
\text { each sample using Luminex } \\
\text { multianalyte profiling (xMAP) } \\
\text { technology on the BioPlex } \\
\text { instrument. }\end{array}$ & $\begin{array}{l}\text { Salivary levels of } \\
\text { immunosuppressive cytokines, } \\
\text { IL-4, IL-10, IL-13, and IL-1RA, } \\
\text { could prove to be potential } \\
\text { biomarkers of OSCC and can be } \\
\text { further investigated as markers } \\
\text { of early detection and disease } \\
\text { progression. }\end{array}$ \\
\hline 24 & $\begin{array}{l}\text { Investigation and } \\
\text { identification of potential } \\
\text { biomarkers in human saliva } \\
\text { for the early diagnosis of oral } \\
\text { squamous cell carcinoma. }\end{array}$ & $\begin{array}{l}2014 \\
\text { Wang et al }\end{array}$ & $\begin{array}{l}60 \text { ( } 30 \text { OSCC patients and } 30 \\
\text { apparently healthy } \\
\text { individuals) }\end{array}$ & $\begin{array}{l}\text { Ultra-performance liquid } \\
\text { chromatography-mass } \\
\text { spectrometry (UPLC-MS) in } \\
\text { hydrophilic interaction } \\
\text { chromatography mode. }\end{array}$ & $\begin{array}{l}\text { Salivary metabolite biomarkers } \\
\text { for the early diagnosis of OSCC } \\
\text { were verified in this study and } \\
\text { can be applied as a potential } \\
\text { technique of preclinical } \\
\text { screening of OSCC. }\end{array}$ \\
\hline 25 & $\begin{array}{l}\text { Salivary RNA Signatures in } \\
\text { Oral Cancer Detection. }\end{array}$ & $\begin{array}{l}2014 \\
\text { Panta and } \\
\text { Venna }\end{array}$ & & $\begin{array}{l}\text { Quantitative polymerase chain } \\
\text { reaction (qPCR) and } \\
\text { microarrays (proven gold } \\
\text { standard) followed by qPCR are } \\
\text { the principal methods used in } \\
\text { salivary RNA analysis. }\end{array}$ & $\begin{array}{l}\text { Protein phosphatase } 1, \mathrm{H} 3 \\
\text { Histone, Family } 3 \mathrm{~A} \text {, Interleukin } \\
1 \text { Beta, Interleukin } 8 \text {, ornithine } \\
\text { decarboxylase antizyme } 1 \text {, } \\
\text { Spermidine N1- } \\
\text { Acetyltransferase } 1, \mathrm{~S} 100 \\
\text { calcium binding protein P, and } \\
\text { miR-31 are upregulated and the } \\
\text { levels of miR-125a and miR- } \\
\text { 200a are downregulated in oral } \\
\text { cancer patients. }\end{array}$ \\
\hline 26 & $\begin{array}{l}\text { Salivary auto-antibodies as } \\
\text { noninvasive diagnostic } \\
\text { markers of oral cavity } \\
\text { squamous cell carcinoma. }\end{array}$ & $\begin{array}{l}2014 \\
\text { Wu et al }\end{array}$ & 348 & $\begin{array}{l}\text { Multiplexed bead-based } \\
\text { platform was used to } \\
\text { simultaneously detect auto- } \\
\text { antibodies (auto-Abs) in salivary } \\
\text { samples. }\end{array}$ & $\begin{array}{l}\text { Auto-Abs were effective for } \\
\text { distinguishing the well- } \\
\text { differentiated OSCC from other } \\
\text { types. }\end{array}$ \\
\hline
\end{tabular}




\begin{tabular}{|c|c|c|c|c|c|}
\hline No & Title & $\begin{array}{l}\text { Authors/Dat } \\
\text { e of } \\
\text { publication }\end{array}$ & Sample volume & Biomarkers/methods & Conclusions \\
\hline 27 & $\begin{array}{l}\text { Oral Squamous Cell } \\
\text { Carcinoma Detection By } \\
\text { Salivary Biomarkers in a } \\
\text { Serbian Population. }{ }^{(37)}\end{array}$ & $\begin{array}{l}2012 \\
\text { Brinkmann et } \\
\text { al }\end{array}$ & 86 & $\begin{array}{l}\text { Six transcriptome (DUSP1, IL8, } \\
\text { IL1B, OAZ1, SAT1, S100P) } \\
\text { and three proteome (IL1B, IL8, } \\
\text { M2BP) biomarkers were tested } \\
\text { on } 18 \text { early-stage and } 17 \text { late- } \\
\text { stage OSCC patients and 51 } \\
\text { healthy controls using } \\
\text { quantitative PCR and ELISA. }\end{array}$ & $\begin{array}{l}\text { Four transcriptome (IL8, IL1B, } \\
\text { SAT1, S100P) and all proteome } \\
\text { biomarkers were significantly } \\
\text { elevated in OSCC patients. } \\
\text { Patient-based salivary } \\
\text { diagnostics is a highly promising } \\
\text { approach for OSCC detection. }\end{array}$ \\
\hline 28 & $\begin{array}{l}\text { Salivary lncRNA as a } \\
\text { potential marker for oral } \\
\text { squamous cell carcinoma } \\
\text { diagnosis. }\end{array}$ & $\begin{array}{l}2012 \\
\text { Tang et al }\end{array}$ & 20 & Review article & $\begin{array}{l}\text { The findings suggest that the } \\
\text { detection of lncRNAs in saliva } \\
\text { may be used as a noninvasive } \\
\text { and rapid diagnostic tool for the } \\
\text { diagnosis of oral cancer. }\end{array}$ \\
\hline 29 & $\begin{array}{l}\text { Salivary analytes in patients } \\
\text { with oral squamous cell } \\
\text { carcinoma. }^{(39)}\end{array}$ & $\begin{array}{l}2011 \\
\text { Fuchs et al }\end{array}$ & 48 & $\begin{array}{l}\text { Salivary magnesium, calcium, } \\
\text { copper, chloride, phosphate, } \\
\text { potassium, sodium, total } \\
\text { proteins, and amylase were } \\
\text { evaluated. Sodium, potassium, } \\
\text { and chloride were determined by } \\
\text { indirect potentiometry, whereas } \\
\text { copper, magnesium and } \\
\text { phosphate were determined by } \\
\text { atomic absorption } \\
\text { spectrophotometry. }\end{array}$ & $\begin{array}{l}\text { In patients with OSCC, } \\
\text { increased salivary sodium and } \\
\text { chloride might reflect their } \\
\text { overall dehydration status due to } \\
\text { alcohol consumption rather than } \\
\text { a consequence of OSCC itself. }\end{array}$ \\
\hline 30 & $\begin{array}{l}\text { Salivary zinc finger protein } \\
510 \text { peptide as a novel } \\
\text { biomarker for detection of } \\
\text { oral squamous cell carcinoma } \\
\text { in early stages. }\end{array}$ & $\begin{array}{l}2011 \\
\text { Jou et al }\end{array}$ & $\begin{array}{l}77 \text { (47 OSCC patients and } 30 \\
\text { healthy donors) }\end{array}$ & $\begin{array}{l}\text { A total of } 77 \text { salivary samples } \\
\text { from both groups were analyzed } \\
\text { using MALDI-TOF MS } \\
\text { technology. }\end{array}$ & $\begin{array}{l}\text { Identifying 24-mer ZNF510 } \\
\text { peptide as OSCC-related } \\
\text { salivary biomarkers via } \\
\text { proteomic approach proved } \\
\text { useful in adjunct diagnosis for } \\
\text { early detection rather than } \\
\text { specific diagnostic marker for } \\
\text { progression of OSCC patients. }\end{array}$ \\
\hline 31 & $\begin{array}{l}\text { Tumor and salivary matrix } \\
\text { metalloproteinase levels are } \\
\text { strong diagnostic markers of } \\
\text { oral squamous cell carcinoma. } \\
\text { (41) }\end{array}$ & $\begin{array}{l}2011 \\
\text { Stott-Miller } \\
\text { et al }\end{array}$ & $\begin{array}{l}73 \text { (primary OSCC, oral } \\
\text { dysplasia, and control } \\
\text { subjects) }\end{array}$ & $\begin{array}{l}\text { Evaluation of the expression of } \\
\text { MMP1, MMP3, MMP10, and } \\
\text { MMP12 in oral epithelial tissue } \\
\text { using Affymetrix U133 } 2.0 \text { Plus } \\
\text { GeneChip arrays, followed by } \\
\text { quantitative reverse } \\
\text { transcription-PCR (qRT-PCR) } \\
\text { for MMP1, and determination of } \\
\text { MMP1 and MMP3 } \\
\text { concentrations in saliva. }\end{array}$ & $\begin{array}{l}\text { Tumor and salivary MMPs are } \\
\text { robust diagnostic biomarkers of } \\
\text { OSCC. }\end{array}$ \\
\hline 32 & $\begin{array}{l}\text { Salivary proteomics for oral } \\
\text { cancer biomarker discovery. } \\
(42)\end{array}$ & $\begin{array}{l}2008 \\
\text { Hu et al }\end{array}$ & $\begin{array}{l}128 \text { (64 OSCC patients and } 64 \\
\text { healthy subjects) }\end{array}$ & Shotgun proteomics & $\begin{array}{l}\text { Patient-based saliva proteomics } \\
\text { is a promising approach to } \\
\text { searching for OSCC biomarkers. }\end{array}$ \\
\hline 33 & $\begin{array}{l}\text { Concomitant analysis of } \\
\text { salivary tumor markers--a } \\
\text { new diagnostic tool for oral } \\
\text { cancer }^{(43)}\end{array}$ & $\begin{array}{l}2006 \\
\text { Nagler et al }\end{array}$ & 21 tongue OSCC patients & $\begin{array}{l}\text { Carbohydrate antigens CA125 } \\
\text { and CA19-9, TPS, CEA, SCC, } \\
\text { and Cyfra } 21-1 \text { circulatory } \\
\text { tumor markers in the saliva were } \\
\text { evaluated. }\end{array}$ & $\begin{array}{l}\text { The increase reported in salivary } \\
\text { tumor markers may be used as a } \\
\text { diagnostic tool, especially when } \\
\text { a concurrent analysis for } \\
\text { significantly increased markers } \\
\text { is done. }\end{array}$ \\
\hline 34 & $\begin{array}{l}\text { Salivary transcriptome } \\
\text { diagnostics for oral cancer } \\
\text { detection. }\end{array}$ & $\begin{array}{l}2004 \\
\text { Li et al }\end{array}$ & $\begin{array}{l}64(32 \text { primary T1/T2 OSCC } \\
\text { patients and } 32 \text { normal } \\
\text { subjects) }\end{array}$ & $\begin{array}{l}\text { RNA isolation was done from } \\
\text { the saliva supernatant, followed } \\
\text { by two-round linear } \\
\text { amplification with T7 RNA } \\
\text { polymerase. }\end{array}$ & $\begin{array}{l}\text { The utility of salivary } \\
\text { transcriptome diagnostics is } \\
\text { successfully demonstrated in this } \\
\text { study for oral cancer detection. }\end{array}$ \\
\hline
\end{tabular}




\section{Discussion:}

Salivary proteomics is developing through the identification of unique biomarkers for early detection approaches including metabolomics, proteomics, genomics, and bioinformatics. ${ }^{(17)}$ The salivary biomarkers are used because saliva encompasses a wide range of compounds, ${ }^{(45)}$ it is easily accessible, ${ }^{(46)}$ and the sampling process is comfortable for patients. ${ }^{(47)}$ The method is noninvasive and safe with low chances of pathogen transmission in comparison with blood samples. ${ }^{(48)}$ Also, saliva is easy to store ${ }^{(49)}$ and does not coagulate. The systematic analysis of salivary proteomic biomarkers and screening of saliva provides an efficient diagnostic tool to turn salivary diagnostics into clinical reality for oral cancer. Because of cellular and molecular heterogeneity of OSCC, several genes are involved in oral carcinogenesis; therefore, the use of several potential biomarkers renders a more precise diagnosis than the use of any marker alone. ${ }^{(17)}$ In Addition, due to the characteristics of saliva, such as its proximity with the oral cavity and noninvasive sampling, the focus on OSCC has been changed to serum and saliva analysis as an alternative to tissue analysis. ${ }^{(17)}$ Salivary biomarkers of OSCC can be used for cancer detection and monitoring non-cancerous activities. ${ }^{(17)}$ The salivary biomarkers discussed in this study can be used for the detection of altered mRNA transcripts and changed intra-cellular or extra-cellular protein levels, and they can be genetic, protein, or metabolomic biomarkers, ${ }^{(45)}$ The detection of these changes by the use of new technologies such as mass spectrometry, gel electrophoresis, chromatography, microarrays, high performance liquid chromatography (HPLC), polymerase chain reaction (PCR), and enzyme-linked immunosorbent assay (ELISA) is a developing field associated with point-of-care technologies, electrochemical detection, RNA sequencing, and liquid biopsy. ${ }^{(17)}$ Furthermore, primary screening by the use of saliva could be an excellent choice considering the advancements in proteomics and genomics.

The extensive sighting of biomarkers and their authentication will change the field of diagnosis for oral cancers and non-cancerous activities. This review provides a comprehensive assessment of the developing diagnostic proteomic tools and biomarkers for the early detection and diagnosis of OSCC by the use of saliva.

\section{Conclusion:}

According to the reviewed studies, salivary biomarker analysis seems to be a major development in the diagnosis of OSCC, and it is a fastgrowing field in scientific research. The results show that salivary biomarkers can be a useful diagnostic and prognostic tool in OSCC.

\section{References:}

1. Ferlay J, Soerjomataram I, Dikshit R, Eser S, Mathers C, Rebelo M, et al. Cancer incidence and mortality worldwide: sources, methods and major patterns in GLOBOCAN 2012. Int J Cancer 2015 Mar 1;136(5):E359-86.

2 . Attar E, Dey S, Hablas A, Seifeldin IA, Ramadan M, Rozek LS, et al. Head and Neck Cancer in a Developing Country: A Population-Based Perspective Across 8 Years. Oral Oncol 2010 Aug; 46(8):591-6.

3.Bagan J, Sarrion G, Jimenez Y. Oral Cancer: Clinical Features. Oral Oncol 2010 Jun;46(6):414-7.

4.Abbasi F, Farhadi S, Esmaili M. Efficacy of Pilocarpine and Bromhexine in Improving Radiotherapy-induced Xerostomia. J Dent Res Dent Clin Dent Prospects. 2013 May;7(2):86-90.

5 Ford PJ, Farah CS. Early detection and diagnosis of oral cancer: Strategies for improvement. J Cancer Policy 2013 Mar-Jun;1(1-2):e2-e7.

6. Shahsavari F, Farhadi S, Sadri D, Sedehi M. Evaluation of Microvascularity by CD34 Expression in Esophagus and Oral Squamous Cell Carcinoma. J Contemp Dent Pract 2015 Jun 1;16(6):458-62.

7. Sargolzaei S, Farhadi S, Kazemi B, Bandehpour M, Kharazifard MJ. The correlation between p16 expression and INK4a locus mutation with grades and stages in oral squamous cell carcinoma. Indian J Pathol Microbiol. 2014 JanMar;57(1):24-30.

8. Shah FD, Begum R, Vajaria BN, Patel KR, Patel JB, Shukla SN, et al. A review on salivary genomics and proteomics biomarkers in oral cancer. Indian J Clin Biochem. 2011 Oct;26(4):326334. 
9. Markopoulos AK, Michailidou EZ, Tzimagiorgis G. Salivary markers for oral cancer detection. Open Dent J 2010 Aug;4:172-8.

10. Bano S, David MP, Indira AP. Salivary biomarkers for oral squamous cell carcinoma: an overview. IJSS Case Rep Rev. 2015;1(8):39-45

11. Cheng YL, Jordan L, Chen HS, Kang D, Oxford L, Plemons J, et al. Chronic periodontitis can affect the levels of potential oral cancer salivary mRNA biomarkers. J Periodontal Res 2017 Jun;52(3):428-37.

12. Chen YT, Chen HW, Wu CF, Chu LJ, Chiang WF, Wu CC, et al. Development of a Multiplexed Liquid Chromatography Multiple-Reaction-Monitoring Mass Spectrometry (LC-MRM/ MS) Method for Evaluation of Salivary Proteins as Oral Cancer Biomarkers. Mol Cell Proteomics 2017 May;16(5):799-811.

13. Ohshima M, Sugahara K, Kasahara K, Katakura A. Metabolomic analysis of the saliva of Japanese patients with oral squamous cell carcinoma. Oncol Rep 2017 May;37(5):2727-34.

14. Sahibzada HA, Khurshid Z, Khan RS, Naseem M, Siddique KM, Mali M, et al. Salivary IL-8, IL-6 and TNF- $\alpha$ as Potential Diagnostic Biomarkers for Oral Cancer. Diagnostics (Basel) 2017 Apr 9;7(2). pii: E21.

15. Ghallab NA, Shaker OG. Serum and salivary levels of chemerin and MMP-9 in oral squamous cell carcinoma and oral premalignant lesions. Clin Oral Investig 2017 Apr;21(3):937-47.

16. Stuani VT, Rubira CM, Sant'Ana AC, Santos PS. Salivary biomarkers as tools for oral squamous cell carcinoma diagnosis: A systematic review. Head Neck 2017 Apr;39(4):797-811.

17. Sannam Khan R, Khurshid Z, Akhbar S, Faraz Moin S. Advances of Salivary Proteomics in Oral Squamous Cell Carcinoma (OSCC) Detection: An Update. Proteomes 2016 Dec 15;4(4). pii: E41.

18. Radhika T, Jeddy N, Nithya S, Muthumeenakshi RM. Salivary biomarkers in oral squamous cell carcinoma - An insight. J Oral Biol Craniofac Res 2016 Nov; 6(Suppl 1): S51-S54.

19. Michailidou E, Tzimagiorgis G, Chatzopoulou F, Vahtsevanos K, Antoniadis K, Kouidou S, et al. Salivary mRNA markers having the potential to detect oral squamous cell carcinoma segregated from oral leukoplakia with dysplasia. Cancer Epidemiol 2016 Aug;43:112-8.

20. Gleber-Netto FO, Yakob M, Li F, Feng Z, Dai
J, Kao HK, et al. Salivary Biomarkers for Detection of Oral Squamous Cell Carcinoma in a Taiwanese Population. Clin Cancer Res. 2016 Jul 1;22(13):3340-7.

21. Malhotra R, Urs AB, Chakravarti A, Kumar S, Gupta VK, Mahajan B. Correlation of Cyfra 21-1 levels in saliva and serum with CK19 mRNA expression in oral squamous cell carcinoma. Tumour Biol 2016 Jul;37(7):9263-71.

22. Jacob TV, Ramesh M, Murali S, Ramesh K, Sanjay PR, Abraham P. A non-invasive study to estimate and compare salivary sialic acid level as tumor marker in patients with pre-cancer and oral cancer. J Cancer Res Ther 2016 AprJun;12(2):634-9.

23. Santosh AB, Jones T, Harvey J. A review on oral cancer biomarkers: Understanding the past and learning from the present. J Cancer Res Ther. 2016 Apr-Jun;12(2):486-92.

24. Kaur J, Politis C, Jacobs R. Salivary 8-hydroxy-2-deoxyguanosine, malondialdehyde, vitamin $\mathrm{C}$, and vitamin $\mathrm{E}$ in oral pre-cancer and cancer: diagnostic value and free radical mechanism of action. Clin Oral Investig 2016 Mar;20(2):315-9.

25. Lokesh K, Kannabiran J, Rao MD. Salivary Lactate Dehydrogenase (LDH)- A Novel Technique in Oral Cancer Detection and Diagnosis. J Clin Diagn Res 2016 Feb;10(2):ZC34-7.

26. Oka R, Nakashiro K, Goda H, Iwamoto K, Tokuzen N, Hamakawa H. Annexin A8 is a novel molecular marker for detecting lymph node metastasis in oral squamous cell carcinoma. Oncotarget 2016 Jan 26;7(4):4882-9.

27. Honarmand MH, Farhad-Mollashahi L, Nakhaee A, Nehi M. Salivary Levels of ErbB2 and CEA in Oral Squamous Cell Carcinoma Patients. Asian Pac J Cancer Prev 2016;17(S3):77-80.

28. Metgud R, Bajaj S. Altered serum and salivary $\mathrm{C}$-reactive protein levels in patients with oral premalignant lesions and oral squamous cell carcinoma. Biotech Histochem. 2016;91(2):96101.

29. Gallo C, Ciavarella D, Santarelli A, Ranieri E, Colella G, Lo Muzio L, et al. Potential Salivary Proteomic Markers of Oral Squamous Cell Carcinoma. Cancer Genomics Proteomics 2016 Jan-Feb;13(1):55-61.

30.Winck FV, Prado Ribeiro AC, Ramos Domingues R, Ling LY, Riaño-Pachón DM, Rivera $\mathrm{C}$, et al. Insights into immune responses in 
oral cancer through proteomic analysis of saliva and salivary extracellular vesicles. Sci Rep 2015 Nov 5;5:16305

31. Zahran F, Ghalwash D, Shaker O, Al-Johani $\mathrm{K}$, Scully C. Salivary microRNAs in oral cancer. Oral Dis 2015 Sep;21(6):739-47.

32. Rajkumar K, Ramya R, Nandhini G, Rajashree P, Ramesh Kumar A, Nirmala Anandan S. Salivary and serum level of CYFRA 21-1 in oral precancer and oral squamous cell carcinoma. Oral Dis 2015 Jan;21(1):90-6.

33. Aziz S, Ahmed SS, Ali A, Khan FA, Zulfiqar G, Iqbal J, et al. Salivary Immunosuppressive Cytokines IL-10 and IL-13 Are Significantly Elevated in Oral Squamous Cell Carcinoma Patients. Cancer Invest 2015;33(7):318-28.

34.Wang Q, Gao P, Wang X, Duan Y. Investigation and identification of potential biomarkers in human saliva for the early diagnosis of oral squamous cell carcinoma. Clin Chim Acta 2014 Jan 1;427:79-85.

35. Panta P, Venna VR. Salivary RNA Signatures in Oral Cancer Detection. Anal Cell Pathol 2014;2014:450629.

36. Wu CC, Chang YT, Chang KP, Liu YL, Liu HP, Lee IL, et al. Salivary auto-antibodies as noninvasive diagnostic markers of oral cavity squamous cell carcinoma. Cancer Epidemiol Biomarkers Prev 2014 Aug;23(8):1569-78.

37. Brinkmann O, Kastratovic DA, Dimitrijevic MV, Konstantinovic VS, Jelovac DB, Antic J, et al. Oral Squamous Cell Carcinoma Detection by Salivary Biomarkers in a Serbian Population. Oral Oncol 2011 Jan;47(1):51-5.

38. Tang H, Wu Z, Zhang J, Su B. Salivary lncRNA as a potential marker for oral squamous cell carcinoma diagnosis. Mol Med Rep 2013 Mar;7(3):761-6.

39. Fuchs PN, Rogić D, Vidović-Juras D, Susić M, Milenović A, Brailo V, et al. Salivary analytes in patients with oral squamous cell carcinoma. Coll Antropol 2011 Jun;35(2):359-62.

40. Jou YJ, Lin CD, Lai CH, Tang $\mathrm{CH}$, Huang $\mathrm{SH}$, Tsai $\mathrm{MH}$, et al. Salivary zinc finger protein 510 peptide as a novel biomarker for detection of oral squamous cell carcinoma in early stages. Clin Chim Acta 2011 Jul 15;412(15-16):1357-65. 41. Stott-Miller M, Houck JR, Lohavanichbutr P, Méndez E, Upton MP, Futran ND, et al. Tumor and salivary matrix metalloproteinase levels are strong diagnostic markers of oral squamous cell carcinoma. Cancer Epidemiol Biomarkers Prev 2011 Dec;20(12):2628-36.

42. Hu S, Arellano M, Boontheung P, Wang J, Zhou H, Jiang J, et al. Salivary proteomics for oral cancer biomarker discovery. Clin Cancer Res 2008 Oct 1;14(19):6246-52.

43. Nagler R, Bahar G, Shpitzer T, Feinmesser R. Concomitant analysis of salivary tumor markers-a new diagnostic tool for oral cancer. Clin Cancer Res 2006 Jul 1;12(13):3979-84.

44. Li Y, St John MA, Zhou X, Kim Y, Sinha U, Jordan RC, et al. Salivary transcriptome diagnostics for oral cancer detection. Clin Cancer Res 2004 Dec 15;10(24):8442-50.

45. Spielmann N, Wong DT. Saliva: diagnostics and therapeutic perspectives. Oral Dis 2011 May;17(4):345-54

46. Mishra A, Verma M. Cancer biomarkers: are we ready for the prime time? Cancers (Basel) 2010 Mar 22;2(1):190-208.

47. Tanaka T, Tanaka M, Tanaka T. Oral carcinogenesis and oral cancer chemoprevention: A review. J Pathol Res Int 2011;2011:431246.

48. Yoshizawa JM, Schafer CA, Schafer JJ, Farrell JJ, Paster BJ, Wong DT. Salivary biomarkers: toward future clinical and diagnostic utilities. Clin Microbiol Rev 2013 Oct;26(4):781-91. 49. Cheng YS, Rees T, Wright J. A review of research on salivary biomarkers for oral cancer detection. Clin Transl Med 2014 Feb 24;3(1):3. 